\title{
ANMED ÜZERINE
}

Çisem Gündüz Arabacı

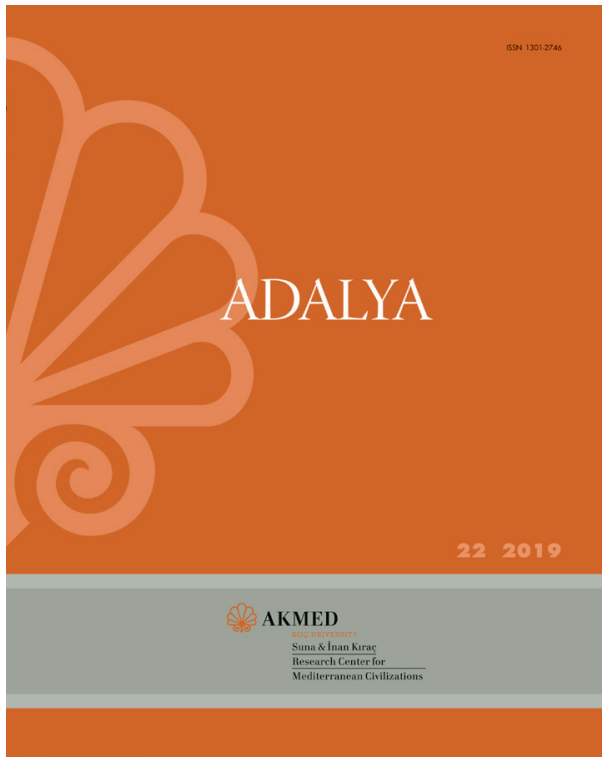

Kısaca AKMED olarak tanınan, Koç Üniversitesi'ne bağlı Suna \& İnan Kıraç Akdeniz Medeniyetleri Araştırma Merkezi'nin süreli yayını Adalya, açı erişimli bir dergi olup yılda bir kez olmak üzere güz aylarında yayımlanıyor. Dergi arşivine, https://akmed.ku.edu.tr/adalya/adalya-arsiv adresinden ulaşılabiliyor. İlk sayısı, 1996 yılında yayınlanan derginin 2020 yılı itibariyle, 23. sayısı yayımlanmış olacak. 1996-2005 yılları arasında, 'Uluslararası Hakemli Dergi' statüsünde olan Adalya, 2006 yllından bu yana A\&HCI (Arts \& Humanities Citation Index) ve CC/A\&H (Current Contents) Arts \& Humanities) tarafından ve Tübitak/ Ulakbim Tr Dizin Sosyal ve Beșeri Bilimler Veri Tabanı'nda taranıyor.

Derginin kapsamını; Cebelitarık'tan Levant'a, Avrupa'nın güneyinden Kuzey Afrika'ya değin yayılan Akdeniz dünyası kültürlerinin; tarih, arkeoloji, sanat tarihi ve bunlarla ilişkili diğer disiplinler kapsamında araştırılması, incelenmesi, belgelenmesi, korunması ve söz konusu kültürlerin birbirleriyle olan ilişkilerinin yorumlanmasına yönelik makaleler oluşturuyor. Diğer bir deyişle, Eski Yunan şehir devletleriyle, Roma, Bizans ve Osmanlı imparatorluklarının 
yayıldığı Akdeniz coğrafyası derginin kapsamına giriyor. $\mathrm{Bu}$ kapsam, kronolojik olarak, tarih öncesi dönemlerden başlayarak 19. yüzyılın sonuna (ya da gerekli olduğu durumda 20. yüzyılın başına) kadar olan süreyle sınırlı.

\section{Anmed}

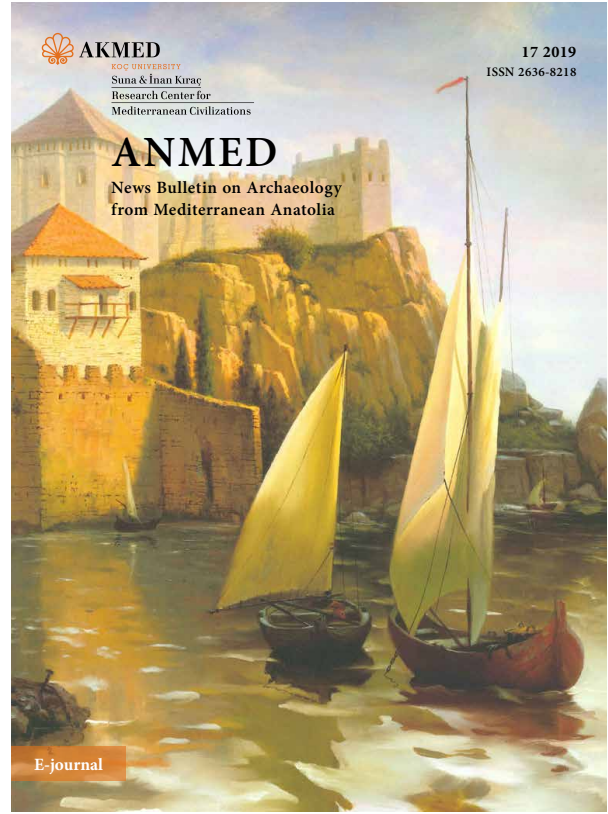

Koç Üniversitesi Suna \& İnan Kıraç Akdeniz Medeniyetleri Araştırma Merkezi'nin süreli yayınlarından diğeriyse, Anmed'dir. Adalya gibi Anmed de açı erişimli bir yayın ve son sayısı da dahil olmak üzere, arșivine https://akmed. ku.edu.tr/yayinlar/anmed-arsiv/ adresinden ulaşmak mümkün.

Yayın hayatına 2003 yılında başlayan dergi, yılda bir kez ve güz aylarında yayımlanıyor. 2020 yılı içinde, 20. sayısı yayımlanacak olan derginin kapsamını; Anadolu Akdenizi olarak tanımlayabileceğimiz Muğla, Antalya, Burdur, Isparta, Karaman, Mersin, Adana, Osmaniye, Kahramanmaraş, Kilis ve Hatay'a kadar yayılan coğrafyada gerçekleştirilen sualtı dahil, arkeolojik kazı ve araştırmalar oluşturuyor. Kronolojik kapsamısa, Prehistorik dönemlerden 19. yüzyıla kadar uzanıyor.
Yukarıda belirtilen kapsam dahilinde kazı ve araştırmalarını gerçekleştiren araştırmacılar, özellikle öne çıkan araştırma sonuçlarından derledikleri raporlarını, Anmed vasıtasıyla tüm dünyaya ulaştırabilme olanağına sahip oluyor. Her sayıda, bir önceki yılın raporlarına yer verilen dergi, İngilizce ve Türkçe olmak üzere, iki dilli olarak yayınlanıyor. 